\title{
High extracellular pressure promotes gastric cancer cell adhesion, invasion, migration and suppresses gastric cancer cell differentiation
}

\author{
CHANGLEI SU ${ }^{1 *}$, BOMIAO ZHANG ${ }^{2 *}$, WENZHI LIU ${ }^{3}$, HONGQUN ZHENG $^{4}$, LINGYU SUN $^{4}$, JINXUE TONG $^{4}$, \\ TIAN WANG ${ }^{3}$, XIAOFENG JIANG $^{5}$, HONGYAN LIANG $^{5}$, LI XUE $^{5}$ and QIFAN ZHANG ${ }^{4}$ \\ ${ }^{1}$ Department of General Surgery, The Second Hospital of Harbin Medical University, Harbin 150001; \\ ${ }^{2}$ Department of Colorectal Surgery, The Third Affiliated Hospital of Harbin Medical University, Harbin 150040; \\ ${ }^{3}$ College of Automation, Harbin Engineering University, Harbin 150001; ${ }^{4}$ Department of Surgical Oncology and \\ ${ }^{5}$ Clinical Laboratory, The Fourth Hospital of Harbin Medical University, Harbin 150001, P.R. China
}

Received December 29, 2015; Accepted April 15, 2016

DOI: $10.3892 /$ or.2016.4841

\begin{abstract}
Slightly increased pressure stimulates tumor cell adhesion and proliferation. In the present study, we aimed to evaluate the effects of high pressure on gene expression and the biological behavior of gastric cancer cells. After incubation for $30 \mathrm{~min}$ at $37^{\circ} \mathrm{C}$ under ambient and increased pressure, one portion of SGC7901 cells was used for cell proliferation and apoptosis assays, cell cycle analysis, adhesion invasion or migration assays. The other portion of cells was harvested for detection of matrix metalloproteinase-2 (MMP-2), inhibitor of DNA binding-1 (ID1), sonic Hedgehog (SHH) and E-cadherin expression by western blotting or RT-PCR. In addition, we investigated the effects of high pressure on SGC7901 cell ultrastructure by transmission electron microscopy. We found that the adhesion fold under increased pressure of 760 and $1,520 \mathrm{mmHg}$ was $2.39 \pm 1.05(\mathrm{P}<0.05)$ and $2.47 \pm 0.85(\mathrm{P}<0.01)$ as compared with the control, respectively. The invasion fold was 3.42 $\pm 2.06(\mathrm{P}<0.05)$ and $5.13 \pm 2.49(\mathrm{P}<0.01)$ as compared with the control, respectively. The migration was $1.65 \pm 0.20$ $(\mathrm{P}<0.001)$ and $2.53 \pm 0.50(\mathrm{P}<0.001)$ as compared with the control, respectively. At increased pressure, MMP-2 and ID1 expression increased significantly, while the expression of $\mathrm{SHH}$ decreased significantly. However, we did not find significant change in proliferation, apoptosis, cell cycle or ultrastructure of the SGC7901 cells under high pressure. In conclusion, high pressure promoted the adhesion, invasion and migration of SGC7901 cells. Moreover, the present study suggests that the pressure-augmented invasion and migration may be related to
\end{abstract}

Correspondence to: Dr Qifan Zhang, Department of Surgical Oncology, The Fourth Hospital of Harbin Medical University, Harbin 150001, P.R. China

E-mail: qifanzhang@hotmail.com

*Contributed equally

Key words: gastric cancer, pressure, adhesion, invasion, migration, differentiation the increase in MMP-2 expression. Moreover, high pressure may suppress SGC7901 cell differentiation, which may result from the change in SHH and ID1 expression.

\section{Introduction}

Gastric cancer (GC) is one of the most common cancers worldwide and $42 \%$ of the cases are reported in China alone (1). Although surgical treatment and chemotherapy have greatly progressed in recent years, the prognosis of advanced GC patients remains poor (2). According to statistics, 10,900 GC deaths were projected to occur in the US in 2013, accounting for $2 \%$ of the estimated total cancer deaths (3). Adhesion of GC cells at a distant site is closely related to the metastasis of GC, which is the leading cause of mortality for GC patients. It is vital for tumor cells to adapt to extracellular environments. The slight increase in extracellular pressure has been found to stimulate tumor cell adhesion in several types of human cancers, such as colon, tongue and breast cancer (4-6).

However, to the best of our knowledge, this is the first study evaluating the influence of high extracellular pressure on gene expression and the biological behavior of GC cells. This is important since clarifying the mechanism of the effect of high extracellular pressure on tumor cells may ultimately provide new therapeutics to suppress tumor growth. In the present study, SGC7901 cells were incubated in RPMI-1640 medium for $30 \mathrm{~min}$ at $37^{\circ} \mathrm{C}$ under ambient and increased pressure $(760$ and $1,520 \mathrm{mmHg}$ ) conditions. Thus, we investigated the effects of high pressure on SGC7901 cell proliferation, apoptosis, adhesion, invasion, migration, differentiation and examined the expression of matrix metalloproteinase-2 (MMP-2), inhibitor of DNA binding-1 (ID1), sonic Hedgehog $(\mathrm{SHH})$ and E-cadherin in the three groups.

\section{Materials and methods}

Cells and reagents. Human GC cell line SGC7901 was cultured in RPMI-1640 medium (Invitrogen, Carlsbad, CA, USA) supplemented with $10 \%$ fetal bovine serum (FBS) and $1 \%$ 
penicillin/streptomycin. The primary antibodies used included anti-ID1 (1:1,000), anti-SHH $(1: 1,000)$, anti-E-cadherin (1:1,000), anti-MMP-2 (1:500) (all from ProteinTech Group, Chicago, IL, USA) and anti- $\beta$-actin $(1: 1,000$; Boster Bioengineering, Wuhan, China).

Western blotting. We studied the expression of ID1, SHH, E-cadherin and MMP-2 under increased or ambient pressure for $30 \mathrm{~min}$ in SGC7901 cells after lysing by standard methods. Fifteen milliliters of each sample was separated by sodium dodecyl sulfate-polyacrylamide gel electrophoresis before transfer to nitrocellulose membranes. The membranes were then blocked with buffer [Tris-buffered saline (TBS), $0.1 \%$ Tween-20 and 5\% non-fat dry milk] for $60 \mathrm{~min}$ at room temperature and incubated with the primary antibody overnight at $4^{\circ} \mathrm{C}$. After washing three times with Tris-buffered solution with Tween-20 (TBST), the membranes underwent hybridization with the horseradish peroxidase-conjugated secondary antibody for $60 \mathrm{~min}$ at room temperature. Membrane-bound secondary antibody was washed three times with TBST and detected by chemiluminescence with the Western Blotting Luminal reagent (Santa Cruz Biotechnology, Santa Cruz, CA, USA) according to the manufacturer's instructions.

Pressure regulation. Ambient pressure was controlled using an airtight pressure tank with inlet and outlet valves, an anthracometer, a thermometer and a manometer for pressure measurement. The carbon dioxide concentration was regulated to within $\pm 0.5 \%$, temperature within $\pm 1^{\circ} \mathrm{C}$ and pressure within $\pm 1.5 \mathrm{mmHg}$.

Matrix pre-coating. Matrigel matrix (BD Biosciences, Bedford, MA, USA) was pre-coated at saturating densities onto 96-well plates or Transwell inserts using serum-free RPMI-1640 medium for $60 \mathrm{~min}$ at $37^{\circ} \mathrm{C}$.

Cell adhesion assay. For the adhesion experiments, the SGC7901 cells were suspended in RPMI-1640 medium and seeded into 96 -well plates $\left(10^{4}\right.$ cells/well $)$ coated with Matrigel. The cells were then incubated for $30 \mathrm{~min}$ at $37^{\circ} \mathrm{C}$ under ambient and increased pressure (760 and 1,520 $\mathrm{mmHg}$ ) conditions. Next, non-adherent cells were gently removed by two washes with warmed phosphate-buffered saline (PBS) After washing, $100 \mu \mathrm{l}$ of RPMI-1640 medium and $10 \mu \mathrm{l}$ of Cell Counting Kit-8 (CCK-8; Boster Bioengineering) were added to each well, and the fluorescence intensity was measured using Tecan EVOlyzer at 60 min after CCK-8 administration (excitation, $450 \mathrm{~nm}$; emission, $630 \mathrm{~nm}$ ). After fluorescence measurement, attached cells were ethanol-fixed, crystal violetstained and observed by an Olympus microscope.

Cell cycle analysis. SGC7901 cells were incubated for $30 \mathrm{~min}$ at $37^{\circ} \mathrm{C}$ under ambient and increased pressure (760 and $1,520 \mathrm{mmHg}$ ) conditions. Twenty-four hours after incubation under increased pressure, the cells were then harvested, washed and fixed with ethanol. Cell cycle distribution was analyzed by FACSCalibur flow cytometry (BD Biosciences).

Transwell invasion assay. Cell invasion assays were performed using Transwell inserts (Corning Costar, Cambridge, MA,
USA), which consist of 12-well Transwell tissue culture plates with $8-\mu \mathrm{m}$ pore size membranes coated with Matrigel (upper chamber). After $24 \mathrm{~h}$ of serum starvation, the SGC7901 cells were incubated for $30 \mathrm{~min}$ at $37^{\circ} \mathrm{C}$ under ambient and increased pressure $(760$ and $1,520 \mathrm{mmHg}$ ) conditions. Cells $(10,000$ cells/well) in serum-free medium were then added to the upper chambers of the Transwell inserts, and the lower chambers were filled with medium containing $10 \%$ FBS. After incubation for another $24 \mathrm{~h}$ at $37^{\circ} \mathrm{C}$, the cells on the upper chamber were scraped with a cotton swab. The invasive cells that passed through the filter were measured according to the manufacturer's instructions. All of the experiments were performed in triplicate and independently repeated three times.

Transwell migration assay. Cell migration assays were performed using Transwell inserts (Corning Costar), which consisted of 12-well Transwell tissue culture plates with $8-\mu \mathrm{m}$ pore size membranes not coated with Matrigel. After $24 \mathrm{~h}$ of serum starvation, the SGC7901 cells were incubated for $30 \mathrm{~min}$ at $37^{\circ} \mathrm{C}$ under ambient and increased pressure (760 and $1,520 \mathrm{mmHg}$ ) conditions. Cells $(10,000$ cells/well) in serum-free medium were then added to the upper chambers of the Transwell inserts, and the lower chambers were filled with medium containing 10\% FBS. After incubation for another $24 \mathrm{~h}$ at $37^{\circ} \mathrm{C}$, the cells on the upper chamber were scraped with a cotton swab. The invasive cells that passed through the filter were measured according to the manufacturer's instructions. All of the experiments were performed in triplicate and independently repeated three times.

Extraction of total RNA and polymerase chain reaction $(P C R)$. TRIzol reagent (Invitrogen) was used to lyse cells and extract total RNA according to the manufacturer's instructions. GAPDH was used as an internal control. For semi-quantitative reverse transcription PCR (RT-PCR), the primer sequences were as follows: forward, 5'-CCCATTCTGTTTCAGCCAGT-3' and reverse, 5'-TTGCTCACCTTGCGGTTC-3' for ID1; forward, 5'-GAGTGAAACTGCGGGTGA-3' and reverse, 5'-CCAGGAAAGTGAGGAAGTCG for SHH; forward, 5'-CC GTGTGAAGTATGGGAACG-3' and reverse, 5'-CGGTCGT AGTCCTCAGTGGT-3' for MMP-2; forward, 5'-GTGAAGG TCGGAGTCAACGG-3' and reverse, 5'-CTCCTGGAAGA TGGTGATGGG-3' for GAPDH. Following RT-PCR, the amplified samples were stained with ethidium bromide and separated using electrophoresis in $2 \%$ agarose gels. The agarose gels were then viewed and photographed under ultraviolet illumination.

Transmission electron microscopy (TEM). SGC7901 cells were incubated for $30 \mathrm{~min}$ at $37^{\circ} \mathrm{C}$ under ambient and increased pressure (760 and $1,520 \mathrm{mmHg}$ ) conditions. Twenty-four hours after incubation under increased pressure, the cells were then harvested, washed and fixed in mixtures of $2.5 \%$ ice-cold glutaraldehyde in $0.1 \mathrm{M}$ sodium cacodylate buffer for $24 \mathrm{~h}$. Next, the cells were rinsed with PBS, postfixed in $2 \%$ osmium tetraoxide (in the same buffer) for $60 \mathrm{~min}$, and dehydrated in a series of graded ethanol. The cells were then incubated in propylene oxide and embedded in TAAB epoxy resin. Following counterstaining with lead citrate and uranyl acetate, ultrathin sections $(50 \mathrm{~nm})$ were placed under 
A

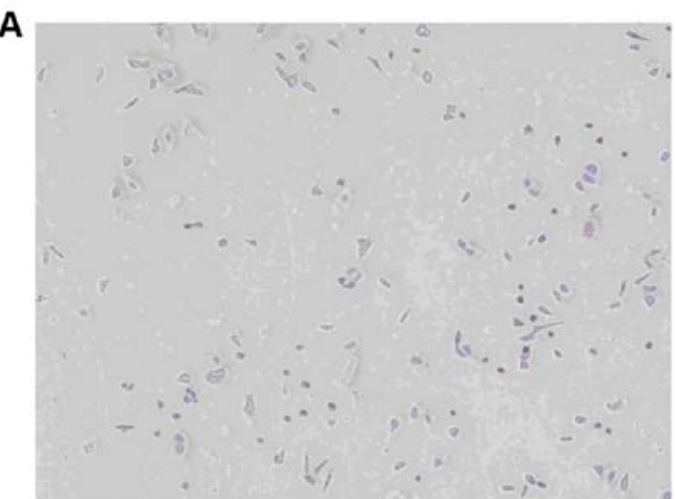

C

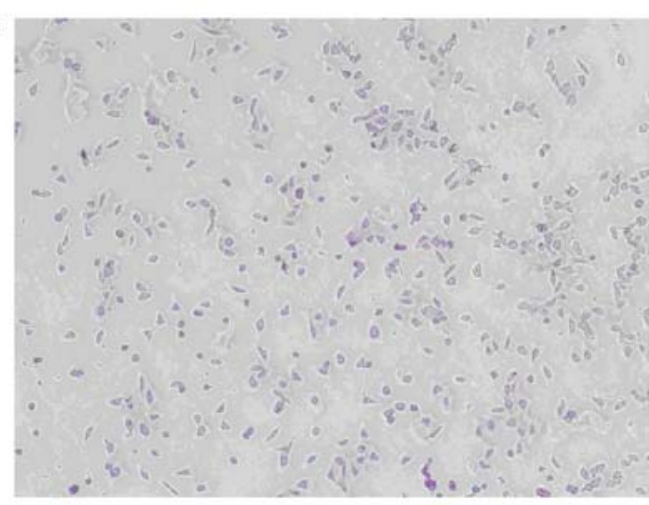

B
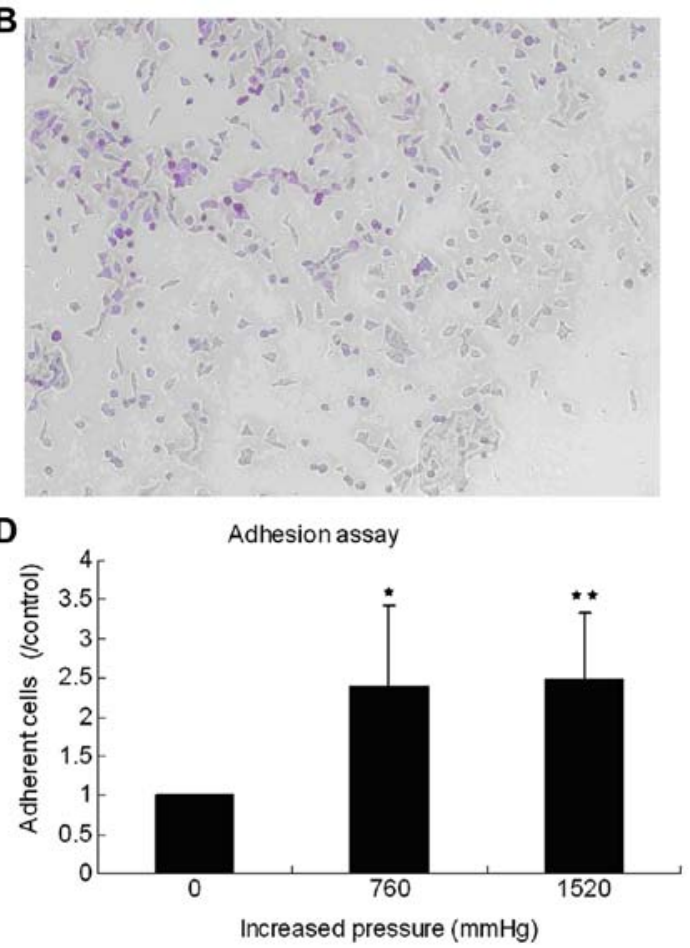

Figure 1. Increasing extracellular pressure promotes gastric cancer cell adhesion. Adhesion assay in SGC7901 cells (magnification, x200). (A) Ambient pressure. (B) Increased pressure of $760 \mathrm{mmHg}$. (C) Increased pressure of 1,520 $\mathrm{mmHg}$. The histogram of adhesion assay is representative of relative adhesion fold as compared with ambient pressure control $(\mathrm{D}) .(\mathrm{n}=3)\left({ }^{\star} \mathrm{P}<0.05 ;{ }^{\star} \mathrm{P}<0.01\right)$.

200 mesh standard copper grids and visualized using a Hitachi H-7500 transmission electron microscope.

Cell proliferation assay. For the cell proliferation assay, the SGC7901 cells were seeded into 96 -well plates $\left(10^{4}\right.$ cells/well) and allowed to attach overnight. The cells were then incubated for $30 \mathrm{~min}$ at $37^{\circ} \mathrm{C}$ under ambient and increased pressure (760 and $1,520 \mathrm{mmHg}$ ) conditions. Seventy-two hours after incubation under increased pressure, the cells were washed twice with PBS. Next, $100 \mu 1$ of RPMI-1640 medium and $10 \mu \mathrm{l}$ of CCK-8 were added to each well, and the fluorescence intensity was measured using Tecan EVOlyzer at 60 min after CCK-8 administration (excitation, $450 \mathrm{~nm}$; emission, $630 \mathrm{~nm}$ ).

Apoptosis assay. SGC7901 cells were incubated for $30 \mathrm{~min}$ at $37^{\circ} \mathrm{C}$ under ambient and increased pressure (760 and $1,520 \mathrm{mmHg}$ ) conditions. Twenty-four hours after incubation under increased pressure, the cells were harvested and washed twice with PBS. The cells were then labeled with Annexin V-fluorescein isothiocyanate and propidium iodide according to the manufacturer's instructions (BD Biosciences) and were analyzed by FACSCalibur flow cytometry.

Statistical analyses. Statistical analyses were performed with SPSS software package version 15.0 for Windows. To analyze the statistical significance between groups, the Student's t-test, Spearman rank or ANOVA tests were used. All statistical tests were two-sided. A P-value $<0.05$ was considered to indicate a statistically significant result.

\section{Results}

Effect of extracellular pressure on solution $\mathrm{pH}$. Since the ambient pressure increase may exert effects on the $\mathrm{pH}$ of the solutions, we examined cell culture medium $\mathrm{pH}$ in each study. There was no significant difference between the $\mathrm{pH}$ of the cell culture solutions maintained at ambient and increased pressure at $37^{\circ} \mathrm{C}$ in room air for $30 \mathrm{~min}$.

High extracellular pressure promotes GC cell adhesion. To determine the influence of high extracellular pressure on cell adhesion, human SGC7901 cells were incubated at $37^{\circ} \mathrm{C}$ under ambient and increased pressure $(760$ and $1,520 \mathrm{mmHg}$ ). Increasing extracellular pressure for $30 \mathrm{~min}$ promoted cell adhesion to Matrigel (BD Biosciences). At increased pressure of 760 and $1,520 \mathrm{mmHg}$, the adherent cells were $238.719 \pm 105.0972 \%$ $(\mathrm{P}=0.025)$ and $247.3855 \pm 85.3597 \%(\mathrm{P}=0.003)$ of those at the ambient pressure, respectively (Fig. 1).

High extracellular pressure enhances GC cell invasion and migration. To investigate whether the pressure has a role in cancer metastasis, we evaluated the effect of high extracellular pressure on cell invasion and migration in the SGC7901 cells. At increased pressure of 760 and $1,520 \mathrm{mmHg}$, the invasive cells were $342.08 \pm 206.429 \%(\mathrm{P}<0.05)$, and $513.409 \pm 249.235 \%$ $(\mathrm{P}<0.01)$ of those at the ambient pressure, respectively (Fig. 2). Compared with normal air-pressure control, the fold change of migration was $1.65 \pm 0.20(\mathrm{P}<0.001)$ and $2.53 \pm 0.50(\mathrm{P}<0.001)$, respectively (Fig. 3). 

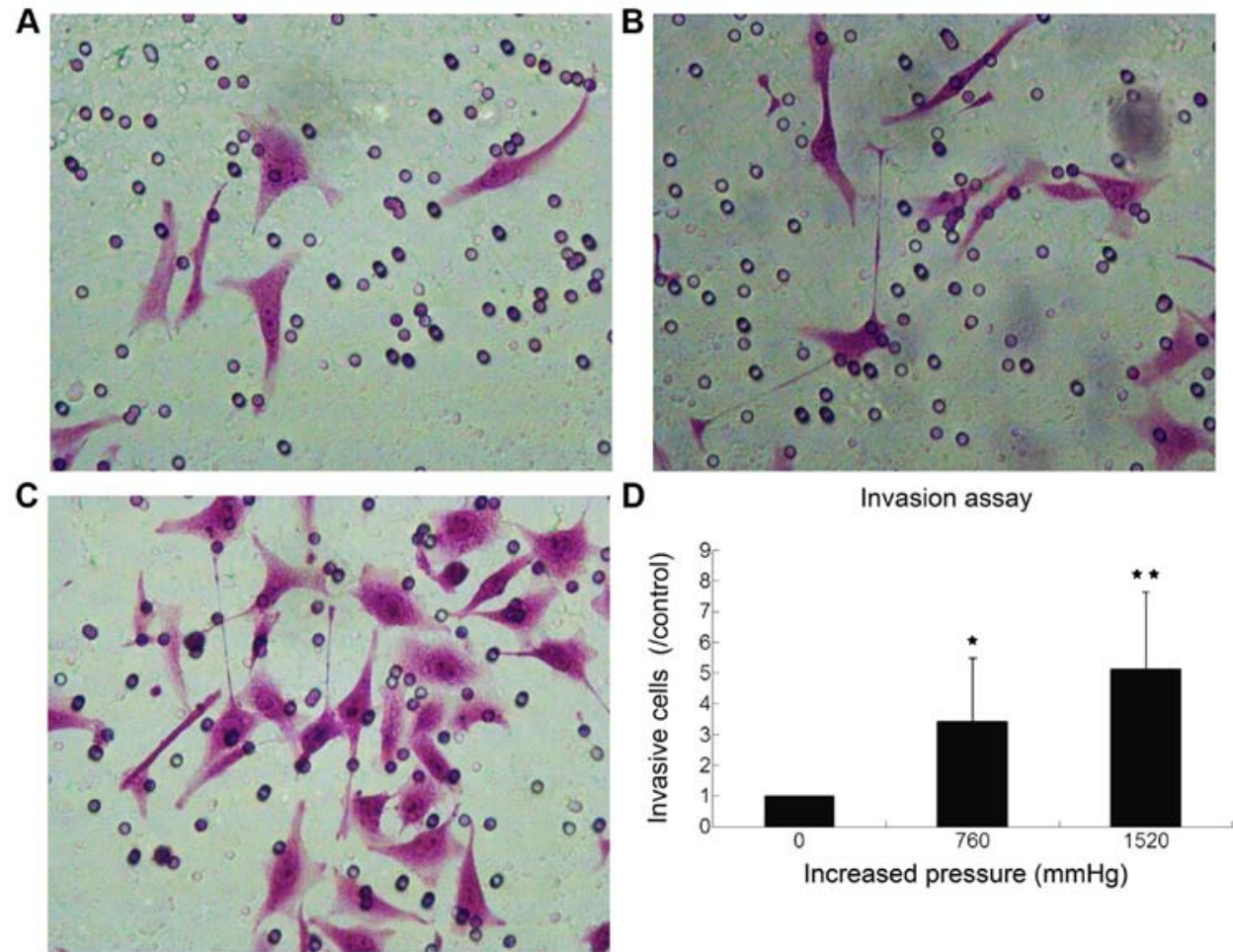

Figure 2. Increasing extracellular pressure promotes gastric cancer cell invasion. Invasion assay in SGC7901 cells (magnification, x200). (A) Ambient pressure. (B) Increased pressure of $760 \mathrm{mmHg}$. (C) Increased pressure of $1,520 \mathrm{mmHg}$. The histogram of the invasion assay is representative of relative invasion fold as compared with normal air-pressure control (D). $(\mathrm{n}=3)\left({ }^{\star} \mathrm{P}<0.05 ;{ }^{\star \star} \mathrm{P}<0.01\right)$.
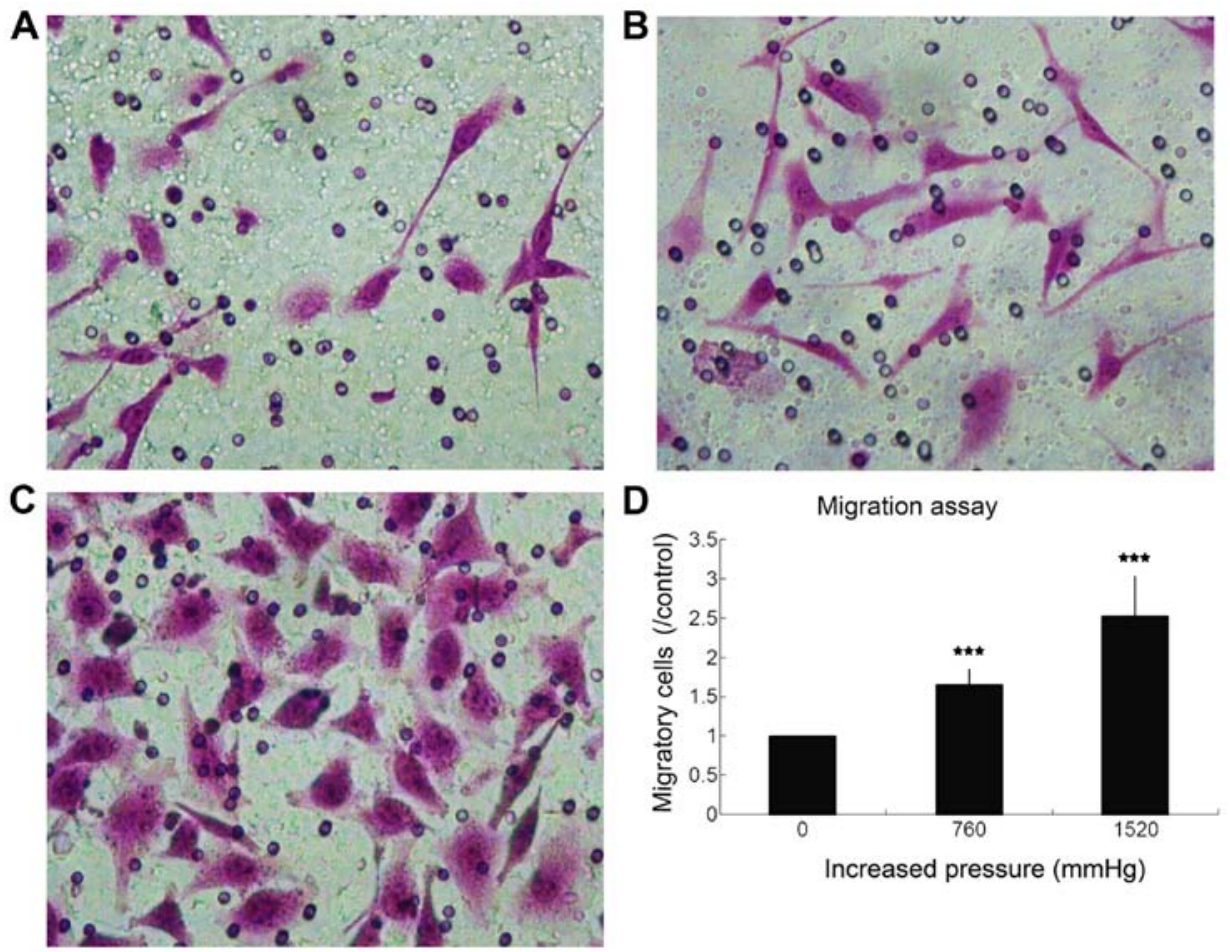

Figure 3. Increasing extracellular pressure promotes gastric cancer cell migration. Migration assay in SGC7901 cells (magnification, x200). (A) Ambient pressure. (B) Increased pressure of $760 \mathrm{mmHg}$. (C) Increased pressure of $1,520 \mathrm{mmHg}$. The diagrams of migration assay is representative of relative migration fold as compared with normal control (D). $(n=3)\left({ }^{\star \star \star} P<0.001\right)$.

Effect of high extracellular pressure on MMP-2, IDI and SHH expression in SGC7901 cells. To further clarify the underlying molecular mechanisms of high extracellular pressure in cancer progression, we examined the gene and protein expression levels of MMP-2 ID1 and SHH in the SGC7901 cells, maintained for 30 min under ambient or increased pressure 


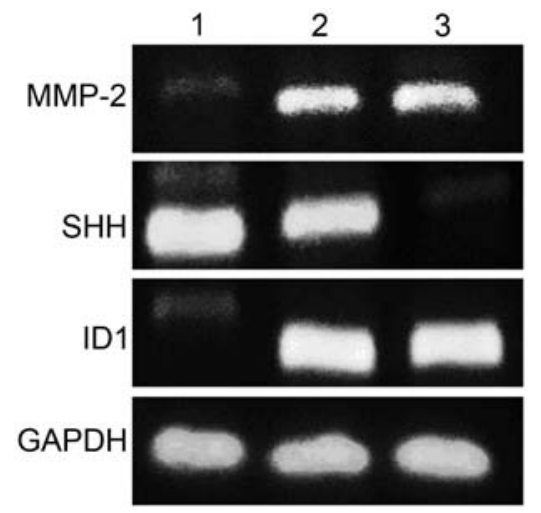

Figure 4. Increasing extracellular pressure influences gene expression in gastric cancer cells. After incubation for $30 \mathrm{~min}$ at $37^{\circ} \mathrm{C}$ under ambient and increased pressure $(760$ and $1,520 \mathrm{mmHg}$ ) conditions, SGC7901 cells were harvested for detection of MMP-2, SHH, ID1 and GAPDH gene expression by RT-PCR. Genes expression in SGC7901 cells. Lane 1, ambient pressure; lane 2, increased pressure of $760 \mathrm{mmHg}$; and lane 3, increased pressure of $1,520 \mathrm{mmHg}$. All assays were performed in triplicate, independently repeated at least three times.

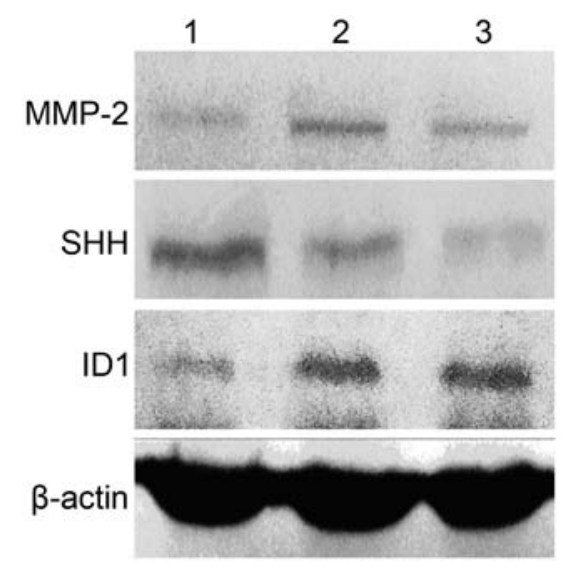

Figure 5. Increasing extracellular pressure influences protein expression in gastric cancer cells. After incubation for $30 \mathrm{~min}$ at $37^{\circ} \mathrm{C}$ under ambient and increased pressure $(760$ and $1,520 \mathrm{mmHg}$ ) conditions, SGC7901 cells were harvested for detection of MMP-2, SHH, ID1 and $\beta$-actin protein expression by western blotting. Protein expression in SGC7901 cells. Lane 1, ambient pressure; lane 2, increased pressure of $760 \mathrm{mmHg}$; and lane 3, lane increased pressure of $1,520 \mathrm{mmHg}$. All assays were performed in triplicate, independently repeated at least three times.

(760 and $1,520 \mathrm{mmHg}$ ) conditions. Pressure of $760 \mathrm{mmHg}$ above ambient stimulated MMP-2 gene expression $(\mathrm{P}<0.01)$ and protein expression $(\mathrm{P}<0.05)$, meanwhile $1,520 \mathrm{mmHg}$ pressure increased MMP-2 gene expression $(\mathrm{P}<0.05)$ and protein expression $(\mathrm{P}<0.05)$. However, there was no significant difference in MMP-2 expression between increased pressure of 760 and $1,520 \mathrm{mmHg}(\mathrm{P}>0.05)$ (Figs. 4 and 5). Pressure of $1,520 \mathrm{mmHg}$ above ambient suppressed SHH gene expression $(\mathrm{P}<0.01)$ and protein expression $(\mathrm{P}<0.05)$, whereas $760 \mathrm{mmHg}$ pressure did not influence SHH gene expression $(\mathrm{P}>0.05)$ and protein expression ( $\mathrm{P}>0.05)$ (Figs. 4 and 5). Pressure of $760 \mathrm{mmHg}$ above ambient stimulated ID1 gene expression $(\mathrm{P}<0.05)$ and protein expression $(\mathrm{P}<0.05)$, meanwhile $1,520 \mathrm{mmHg}$ pressure increased ID1 gene $(\mathrm{P}<0.01)$ and protein expression $(\mathrm{P}<0.01)$. Moreover, there was significant difference in ID1 protein expression between increased pressure of 760 and $1,520 \mathrm{mmHg}(\mathrm{P}<0.05)$ (Figs. 4 and 5).

Effect of high extracellular pressure on proliferation and apoptosis of SGC7901 cells. Although the slight increase in extracellular pressure is reported to promote proliferation of colon cancer cells (7), high extracellular pressure neither significantly influenced cell proliferation as analyzed by CCK- 8 assay (data not shown) nor influenced cell cycle distribution (data not shown), indicating that high extracellular pressure could promote the invasion and migration of the SGC7901 cells without affecting proliferation. In addition, apoptosis analysis of cells $24 \mathrm{~h}$ after treatment with increased pressure demonstrated that the apoptosis level was not statistically significant compared with the normal air-pressure control.

Effect of high extracellular pressure on ultrastructure of SGC7901 cells. SGC7901 cells had large deformed nuclei and prominent nucleoli with abundant rough endoplasmic reticulum, ribosomes and mitochondria in the cytoplasm. Microvilli were also noted in the cytoplasmic membrane. However, there were no prominent changes in cells that were incubated at $37^{\circ} \mathrm{C}$ under increased pressure (Fig. 6).

\section{Discussion}

It has been reported that mildly increasing ambient pressure stimulates adhesion in a variety of human cancer cells (4-6). However, the effect of high extracellular pressure on cell gene expression and the biological behavior in gastric cancer (GC) has not been evaluated. The present study presents the first evidence to assess the impact of highly increased extracellular pressure on cell biological behavior and gene expression in human GC. We found that pressure of 760 and $1,520 \mathrm{mmHg}$ above ambient stimulated cell adhesion to Matrigel. This result is consistent with previous studies in other cell types that increasing ambient pressure to a small degree promoted adhesion (4-6). Studies have shown that the activation of the phosphatidylinositol 3' kinase (PI3K)/Akt signaling pathway is required for pressure-induced tumor cell adhesion (8-10). Pressure results in cytoskeletal independent Src activation that induces PI3K/FAK/Akt pathway activation $(10,11)$. Then, associated with $\mathrm{p} 85$, FAK translocates to the cell membrane and interacts with $\beta 1$ integrin heterodimers, which increases integrin-binding affinity through $\beta 1$ integrin T788/9 phosphorylation and thereby facilitates cancer cell adhesion $(10,12)$. Perry et al (13) found that pressure stimulated FAK and Akt phosphorylation, which was responsible for the pressureaugmented adhesion in sarcoma cell lines. Wang et al (14) identified the AKT1 PH domain and hinge region as structural determinants in permitting AKT1 translocation and phosphorylation and mediating pressure-induced cancer cell adhesion. However, due to diversified ways of regulating tumor cell adhesion (6,15-19), the mechanisms of pressure-stimulated adhesion await further studies.

Since high extracellular pressure was correlated with the adhesion of SGC7901 cells, it is likely that pressure has a role in cancer metastasis. We, therefore, tested the effect of high extracellular pressure on cell invasion and migration in SGC7901 cells. As expected, increasing extracellular pressure 

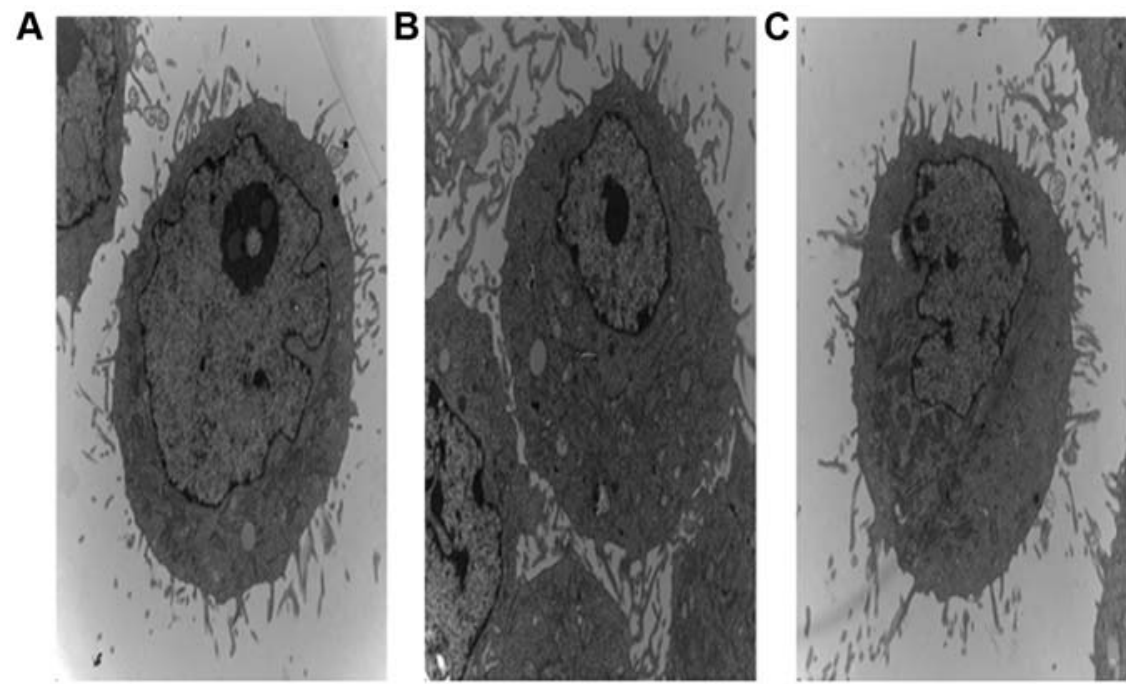

Figure 6. Effect of high extracellular pressure on the ultrastructure of SGC7901 cells (magnification, x10,000). (A) Ambient pressure. (B) Increased pressure of $760 \mathrm{mmHg}$. (C) Increased pressure of $1,520 \mathrm{mmHg}$.

for 30 min promoted the invasion and migration of the SGC7901 cells without affecting proliferation and apoptosis. MMP-2 is a zinc-dependent endopeptidase involved in tumor invasion and migration (20). The overexpression of MMP-2 promotes tumor cell invasion and migration by degrading type IV collagen of the basement membrane and affecting tumor cell adhesion to the basement membrane (20-23). Increasing pressure stimulated MMP-2 expression in the GC cells that we studied. Pressure of $760 \mathrm{mmHg}$ above ambient stimulated MMP-2 gene expression $(\mathrm{P}<0.01)$ and protein expression $(\mathrm{P}<0.05)$, meanwhile $1,520 \mathrm{mmHg}$ pressure increased MMP-2 gene expression $(\mathrm{P}<0.05)$ and protein expression $(\mathrm{P}<0.05)$. This indicates that the high extracellular pressure may promote invasion and migration of SGC7901 cells by enhancing MMP-2 expression.

ID1 protein, belonging to the helix-loop-helix (HLH) protein superfamily, has a highly conserved HLH dimerization domain. Ubiquitously expressed bHLH transcription factors such as the E12/E47 family members or tissue-specific bHLH transcription factors such as Tal-1 and MyoD bind to DNA by means of basic DNA binding regions, and therefore activate the process of cell differentiation. ID1 protein lacks the basic DNA binding domain that is necessary for DNA binding. By forming nonfunctional Id-bHLH heterodimers and sequestering bHLH transcription factors, ID1 proteins serve as negative regulators of bHLH-dependent gene expression and, consequently, of cell differentiation in numerous different cell lineages $(24,25)$.

SHH gene plays a key role in the regulation of cell differentiation, cell proliferation and gastric acid secretion. SHH expression is regulated by gastric acid secretion, pepsin and gastrin (26). By mobilizing intracellular calcium release and protein kinase C (PKC), SHH activates JNK (c-Jun N-terminal kinases) and extracellular signal-regulated kinase (ERK)/mitogen-activated protein kinase (MAPK) signaling pathway, which regulates cell proliferation and differentiation (23-28). SHH, in turn, promotes a negative feedback loop to control gastric acid and gastrin concentration by inducing somatostatin secretion (31).E-cadherin gene, acting as a regulator of cell differentiation, may be a downstream target of the SHH signaling pathway $(29,30)$. However, our data indicate that the high extracellular pressure suppressed SHH expression without affecting E-cadherin expression.

At increased pressure of 760 and $1,520 \mathrm{mmHg}$, we found that the expression of ID1 was significantly increased, while the expression of SHH was significantly decreased. Notably, our data showed that high extracellular pressure neither significantly influenced cell proliferation nor cell apoptosis. In addition, transmission electric microscopy showed that SGC7901 cell ultrastructure did not change significantly under increased pressure conditions. Due to the relationship between tumor differentiation and expression of ID1 and $\mathrm{SHH}$, we speculate that high extracellular pressure may suppress SGC7901 cell differentiation by influencing gene and protein expression.

In conclusion, high extracellular pressure promotes adhesion, invasion and migration of SGC7901 cells, and may suppress SGC7901 cell differentiation. Moreover, the present study suggests that the increase in SGC7901 cell invasion and migration was associated with increased MMP-2 expression. The inhibition of SGC7901 cell differentiation was correlated with the change in SHH and ID1 expression.

\section{Acknowledgements}

We thank Professor Yuru Xu, of the Chinese Academy of Engineering (Harbin Engineering University) for the technical assistance. The present study was financially supported by the Natural Science Foundation of Heilongjiang Province, China (grant no. ZD200920).

\section{References}

1. Parkin DM, Bray F, Ferlay J and Pisani P: Global cancer statistics, 2002. CA Cancer J Clin 55: 74-108, 2005.

2. Catalano V, Labianca R, Beretta GD, Gatta G, de Braud F and Van Cutsem E: Gastric cancer. Crit Rev Oncol Hematol 71: 127-164, 2009

3. Siegel R, Naishadham D and Jemal A: Cancer statistics, 2013. CA Cancer J Clin 63: 11-30, 2013. 
4. Basson $\mathrm{MD}, \mathrm{Yu} \mathrm{CF}$, Herden-Kirchoff $\mathrm{O}$, Ellermeier $\mathrm{M}$ Sanders MA, Merrell RC and Sumpio BE: Effects of increased ambient pressure on colon cancer cell adhesion. J Cell Biochem 78: 47-61, 2000.

5. Conway WC, Van der Voort van Zyp J, Thamilselvan V, Walsh MF, Crowe DL and Basson MD: Paxillin modulates squamous cancer cell adhesion and is important in pressureaugmented adhesion. J Cell Biochem 98: 1507-1516, 2006.

6. Downey C, Alwan K, Thamilselvan V, Zhang L, Jiang Y, Rishi AK and Basson MD: Pressure stimulates breast cancer cell adhesion independently of cell cycle and apoptosis regulatory protein (CARP)-1 regulation of focal adhesion kinase. Am J Surg 192: 631-635, 2006.

7. Walsh MF, Woo RK, Gomez R and Basson MD: Extracellular pressure stimulates colon cancer cell proliferation via a mechanism requiring PKC and tyrosine kinase signals. Cell Prolif 37: 427-441, 2004.

8. Hirabayashi Y, Yamaguchi K, Shiraishi N, Adachi Y, Saiki I and Kitano S: Port-site metastasis after $\mathrm{CO}_{2}$ pneumoperitoneum Role of adhesion molecules and prevention with antiadhesion molecules. Surg Endosc 18: 1113-1117, 2004.

9. Vanhaesebroeck B, Leevers SJ, Ahmadi K, Timms J, Katso R, Driscoll PC, Woscholski R, Parker PJ and Waterfield MD: Synthesis and function of 3-phosphorylated inositol lipids. Annu Rev Biochem 70: 535-602, 2001.

10. Thamilselvan V, Craig DH and Basson MD: FAK association with multiple signal proteins mediates pressure-induced colon cancer cell adhesion via a Src-dependent PI3K/Akt pathway. FASEB J 21: 1730-1741, 2007.

11. Thamilselvan V and Basson MD: The role of the cytoskeleton in differentially regulating pressure-mediated effects on malignant colonocyte focal adhesion signaling and cell adhesion Carcinogenesis 26: 1687-1697, 2005.

12. Craig DH, Gayer CP, Schaubert KL, Wei Y, Li J, Laouar Y and Basson MD: Increased extracellular pressure enhances cancer cell integrin-binding affinity through phosphorylation of beta1integrin at threonine 788/789. Am J Physiol Cell Physiol 296: C193-C204, 2009.

13. Perry BC, Wang S and Basson MD: Extracellular pressure stimulates adhesion of sarcoma cells via activation of focal adhesion kinase and Akt. Am J Surg 200: 610-614, 2010.

14. Wang $S$ and Basson MD: Identification of functional domains in AKT responsible for distinct roles of AKT isoforms in pressurestimulated cancer cell adhesion. Exp Cell Res 314: 286-296, 2008.

15. van Zyp J, Conway WC, Craig DH, van Zyp N, Thamilselvan V and Basson MD: Extracellular pressure stimulates tumor cell adhesion in vitro by paxillin activation. Cancer Biol Ther 5 : 1169-1178, 2006

16. Downey C, Craig DH and Basson MD: Pressure activates colon cancer cell adhesion via paxillin phosphorylation, Crk, Cas, and Rac1. Cell Mol Life Sci 65: 1446-1457, 2008
17. Downey C, Craig DH and Basson MD: Isoform-specific modulation of pressure-stimulated cancer cell proliferation and adhesion by $\alpha$-actinin. Am J Surg 202: 520-523, 2011.

18. Wang $S$ and Basson MD: Integrin-linked kinase: A multi-functional regulator modulating extracellular pressure-stimulated cancer cell adhesion through focal adhesion kinase and AKT. Cell Oncol 31: 273-289, 2009.

19. Li XD, Ji M, Wu J, Jiang JT and Wu CP: Clinical significance of CD44 variants expression in colorectal cancer. Tumori 99: 88-92, 2013.

20. Tester AM, Waltham M, Oh SJ, Bae SN, Bills MM, Walker EC, Kern FG, Stetler-Stevenson WG, Lippman ME and Thompson EW: Pro-matrix metalloproteinase-2 transfection increases orthotopic primary growth and experimental metastasis of MDA-MB-231 human breast cancer cells in nude mice. Cancer Res 64: 652-658, 2004.

21. Kubben FJ, Sier CF, van Duijn W, Griffioen G, Hanemaaijer R, van de Velde CJ, van Krieken JH, Lamers CB and Verspaget HW: Matrix metalloproteinase-2 is a consistent prognostic factor in gastric cancer. Br J Cancer 94: 1035-1040, 2006.

22. Curran S and Murray GI: Matrix metalloproteinases: Molecular aspects of their roles in tumour invasion and metastasis. Eur J Cancer 36: 1621-1630, 2000.

23. Ray JM and Stetler-Stevenson WG: Gelatinase A activity directly modulates melanoma cell adhesion and spreading. EMBO J 14: 908-917, 1995.

24. Norton JD and Atherton GT: Coupling of cell growth control and apoptosis functions of Id proteins. Mol Cell Biol 18: 2371-2381, 1998.

25. Fong S, Debs RJ and Desprez PY: Id genes and proteins as promising targets in cancer therapy. Trends Mol Med 10: 387-392, 2004.

26. Zavros Y, Waghray M, Tessier A, Bai L, Todisco A, L Gumucio D, Samuelson LC, Dlugosz A and Merchant JL: Reduced pepsin A processing of sonic Hedgehog in parietal cells precedes gastric atrophy and transformation. J Biol Chem 282: 33265-33274, 2007.

27. Daulhac L, Kowalski-Chauvel A, Pradayrol L, Vaysse N and Seva C: Gastrin stimulates the formation of a $\mathrm{p} 60^{\mathrm{Src}} / \mathrm{p} 125^{\mathrm{FAK}}$ complex upstream of the phosphatidylinositol 3-kinase signaling pathway. FEBS Lett 445: 251-255, 1999.

28. Dockray G, Dimaline R and Varro A: Gastrin: Old hormone, new functions. Pflugers Arch 449: 344-355, 2005.

29. Feng R, Xiao C and Zavros Y: The role of Sonic Hedgehog as a regulator of gastric function and differentiation. Vitam Horm 88: 473-489, 2012

30. Li X, Deng W, Nail CD, Bailey SK, Kraus MH, Ruppert JM and Lobo-Ruppert SM: Snail induction is an early response to Gli1 that determines the efficiency of epithelial transformation. Oncogene 25: 609-621, 2006. 